\title{
Meesternarratiewe, kontranarratiewe en kanonisering - 'n Perspektief op sommige profetiese geskrifte
}

\author{
A P B Breytenbach \\ Departement Ou-Testamentiese Wetenskap (Afd A) \\ Universiteit van Pretoria
}

\begin{abstract}
Grand narratives, little narratives and canonisation - a perspective on some of the books of the Prophets

The raison d'etre of this study is the problem of normative theological dicta in parts of the Old Testament, which are contradicted in another or even the same book of the Old Testament. In this article canonisation as an ongoing process is investigated from a postmodern perspective which takes contextuality, intertextuality and grand and little narratives into account. The so-called Zion Theology is identified as a grand narrative during the time before and after the Babylonian exile. Books like Jeremiah, Micha, Samuel and Kings, as well as Jonah and Chronicles are referred to in this regard. The research, inter alia, leads to the following result: the normative material of a religious society is interpreted in the light of the prevailing grand narrative. These interpretations are usually added to the normative material. Little narratives, being contradictory to and resisting incorporation into grand narratives, are usually added to the normative material after the grand narrative has been stripped of its hegemony by historic events. This accounts for contradictory theological dicta in the Old Testament. From this follows that the very nature of the canonised material brought together in the Old Testament opposes a fundamentalistic or orthodox theological approach.
\end{abstract}

\section{INLEIDING}

Hierdie artikel vorm deel van die navorsingsprogram van die Fakulteit Teologie (Afd A) aan die Universiteit van Pretoria. Die'huidige navorsing konsentreer onder andere op belydenis en belydenisvorming in dié historiese gemeenskappe waarmee die Nederduitsch Hervormde Kerk doelbewus assosieer. Die impuls wat tot hierdie navorsing aanleiding gegee het, is die hernude belangstelling in die kerk se belydenistradisie en 
die vrae wat dit oproep. Hierdie hernude belangstelling word weerspieël in die volgende besluit van die 64ste Algemene Kerkvergadering van die Nederduitsch Hervormde Kerk van Afrika:

* Die Dosentevergadering ondersoek die volgende vraagstukke, probleme en/of besware teen die inhoud en/of formulering en/of funksie van die belydenisskrifte en lewer verslag aan die eersvolgende Buitengewone Algemene Kerkvergadering:

** Belydenisskrifte is nie ewige, geldende waarhede nie.

** Die leer van die kerk is voortdurende gebeure wat elke keer nuut verstaan en beantwoord moet word en daarom nie onderskryf kan word nie ... (Nederduitsch Hervormde Kerk 1995:330).

Hierdie artikel is bedoel om vanuit die terrein van die Ou-Testamentiese wetenskap deel te wees van die akademiese gesprek oor die genoemde saak.

\section{TEORETIESE BEGRONDING}

Die perspektief van waaruit die onderhawige studie onderneem is, is hoofsaaklik gevorm deur die ontwikkelinge op vier terreine.

\subsection{Die Ou-Testamentiese wetenskap}

Die afgelope dekades het daar belangrike verskuiwings plaasgevind op die terrein van die Ou-Testamentiese wetenskap. Dit was die noodwendige gevolg van navorsing wat oor 'n lang tydperk gedoen is binne die histories-kritiese paradigma. Resultate van veral tradisiekritiek, redaksiekritiek en ideologiekritiek het daartoe gelei dat die beeld van 'n eenduidige 'boodskap' of teologie van die Ou Testament afgebreek is. Daar is tot die oortuiging gekom dat daar nie ' $n$ Mitte is in die versameling boeke wat as die Ou Testament bekend staan nie (Hasel 1972:77-103). Die paradigmaverskuiwing weg van die streng histories-kritiese benadering het hierdie diversiteit in die Ou Testament bevestig. Die klem wat geplaas is op konteks as betekeniskonstituerende element by die lees van tekste, die verbreding van die begrip konteks om ook die leefwêreld van tekste in te sluit, die bewuswording van belangegroepe wat die tekste van die Ou Testament geproduseer het en die rol van lesers in die resepsie van daardie tekste, het verder bygedra tot die oortuiging dat daar nie sprake kan wees van 'n teologie van die $\mathrm{Ou}$ Testament nie, maar wel van teologieë in die Ou Testament. Pogings uit kringe van 
die Biblical Theology-beweging om vanuit ' $n$ kanonbenadering die Ou- en Nuwe Testament onder een teologiese kombers toe te maak, was ook onoortuigend (vgl bv Murphy 1984:65-72).

Hierdie ontwikkeling op die terrein van die Ou-Testamentiese wetenskap is veral in die laaste fase baie sterk beïnvloed deur nuwe insigte in die algemene literatuurwetenskap. Die erkenning dat die boeke van die Ou Testament literatuur is, het kennisname en gebruikmaking van insigte uit die literatuurwetenskap vir die lees en verstaan van die Ou Testament onvermydelik gemaak (vgl bv Nel \& Van den Berg 1995).

\subsection{Historiologiese perspektiewe}

K-E Jeismann (1985:13v) het cortuigend betoog dat die historiese bewussyn van individue en gemeenskappe onder andere twee belangrike funksies vervul, naamlik:

- Vorstellung von Vergangenheit prägt GegenwartsbewuBtsein in einer tiefen, sozialpsychischen, weit ins Unbewußte reichenden Schicht durch die Fundamentierung von Identitätsempfinden und -bewußtsein.

- Eine zweite, klar auszumachende Funktion des Rückgriffs auf Geschichte ist die der Legitimierung von Zuständen oder Ansprüchen.

Geskiedenis word dus vertel om daarmee bewustelik of onbewustelik in die hede die eie identiteit te begrond en om bestaande toestande en aansprake te legitimeer. Die Ou Testament bestaan vir ' $n$ groot deel uit die vertel van geskiedenisse. Aan die woord is dus belangegroepe wat identiteit begrond en aansprake legitimeer.

\subsection{Literatuurwetenskaplike perspektiewe}

Gedurende die afgelope twee dekades het die kulturele verskynsel wat breedweg getipeer word as postmodernisme, 'n koersaanpassing veroorsaak in die literatuurwetenskap (vgl bv Ryan 1988:247-258; Liebenberg 1988:271-286; Olivier 1988:287-298; Gräbe 1988:359-377; Viljoen 1988:417-427; Hutcheon 1988:ix-36; Hambidge 1992a: 62-68; Ibsch 1993:185-193; Van Heerden 1997:11v). Die postmodernisme het as kultuurverskynsel gegroei uit die Amerikaanse proteskultuur van die sestigerjare en ook uit die poststrukturalistiese reaksie van Franse filosowe en literatuur-teoretici soos Derrida, Foucault en Lyotard (Van Heerden 1997:24-33). Postmodernisme is onder andere 'n lees- en skryfperspektief of -strategie (Brink 1988:392) wat, alhoewel dit moeilik 
definieerbaar is vanweë sy veelkantigheid (Van Heerden 1997:13-18) tog sekere prominente aspekte vertoon (Liebenberg 1988:274-275; Hambidge 1992a:62-68; Van Heerden 1997:41-60). Die volgende, waarvan sommige ou insigte is, is vir die doel van hierdie studie van belang:

* Objektiwiteit word ontken. Dit hang saam met die feit dat 'betekenis' altyd kontekstueel is. Dit is natuurlik 'n ou insig. Nietzsche het al gesê: 'Gerade Tatsachen gibt es nicht, nur Interpretationen' (soos aangehaal deur Ibsch 1993:186). Daarby kom nog dat die skrywer se rol as betekenisgewer in die postmodernisme bevraagteken word en die leser se aktiewe rol in die vertolking van 'n teks erken word (Hambidge 1992a:63). Verskillende interpretasies van 'n teks of tekensisteem is dus moontlik. 'Postmodern discourse is critical of both premodernity and modernity for assuming that there is only one correct way of understanding the world, whether mythical or rational. It cultivates a sensitivity for the complexity of human experience and allows for a plurality of ways of interpreting signs' (Degenaar 1995:3).

'n Teks is volgens hierdie siening betekenisloos 'totdat die leser betekenis daaraan toeken' (Hambidge 1992a:65). Dit beteken dat die vertolking van 'n teks 'verander met elke ontvanger of leser wat dit ter hand neem, omdat die ideologiese posisie, leeservaringe én verwagtinge telkens uniek en anders is' (Hambidge 1992a:67).

* In aansluiting by die voorafgaande geld die oortuiging in postmodernistiese kringe dat die werklikheid getekstualiseer en daarom gefiksionaliseer is. Aangesien die skep van literêre produkte altyd binne 'n bepaalde konteks plaasvind en aangesien sogenaamde 'feite' altyd vanuit 'n bepaalde ideologiese posisie 'gelees' en weergegee word, is daar nie wesenlike verskille tussen fiksie en 'feite' nie. 'We cannot know the past except through its texts: its documents, its evidence, even its eyewitness accounts are texts' (Hutcheon 1988:16).

Historiographich metafiction ${ }^{1}$ refutes the natural or common sense methods of distinguishing between historical fact and fiction. It refuses the view that only history has a truth claim, both by questioning the ground of that claim in historiography and by asserting that both history and fiction are discourses, human constructs, signifying systems, and both derive their major claim to truth from that identity.

(Hutcheon 1988:93) 
Dit beteken natuurlik nie dat die werklikheid wat in geskiedskrywing 'beskryf' word, nie bestaan het nie (Van Heerden 1994:4). Dit beteken alleen dat 'n objektiewe optekening van gebeure nie moontlik is nie, en dat 'n een-tot-een verhouding tussen teks en werklikheid dus nie bestaan nie. Fiksie en (historiografiese) metafiksie is net so 'waar' soos historiografie (Viljoen 1988:4i7-426; Ibsch 1993:185-193; Van Heerden 1997:7276).

* Hieruit vloei voort dat daar binne 'n postmodernistiese perspektief 'n grondige wantroue is in meesternarratiewe. J-F Lyotard het met sy onderskeid tussen métarécits (meester- of metanarratiewe of -kodes - vgl Van Heerden 1997:44) en petits récits (klein narratiewe of kleingeskiedenisse) die aandag gevestig op narratiewe $^{2}$ wat pretendeer om universele waarhede bloot te lê.

[A] 'grand narrative' claims to be the story that can reveal the meaning of all stories, be it the weakness or the progress of mankind. Its metanarrative status comes from the fact that it talks about the many narratives of culture so as to reveal the singular truth inherent in them. The implicit epistemological claim of a metanarrative is to put an end to narration by revealing the meaning of narratives. This rests upon the assumption that the force of narratives is synonymous with the meaning that may be found in them, that narrative is to be wholly understood in terms of the production and transmission of meaning, that it is a conceptual instrument of representation.

(Readings 1991:63)

Hierteenoor staan Lyotard se cortuiging: 'For Lyotard, "narrative" is not a concept that allows us to unlock the meaning of culture. Rather it is the rhetorical figure that opens culture as a site of transformation and dispute' (Readings 1991:63). In hierdie 'oopmaak' van die kultuur speel kleingeskiedenisse 'n wesenlike rol, vanweë die feit dat hulle weerstand bied teen 'incorporation into such totalizing histories of cultural representation' (Readings 1991:63), en dat hulle (om Ryan 1988:248v se woorde buite verband aan te haal) gerig is op 'the disabling of majority discourses (those which effectively shut down discursive options by constituting themselves as truth)'.

Die insigte van Lyotard oor kleingeskiedenisse het aangesluit by en is ook aangevul deur Foucault se opvattings oor 'counter-memory' (Van Heerden 1994:7; 1997:44v). 
Foucault het die aandag gevestig op die netwerk diskursiewe magte wat tekste produseer en veral die aandag gevra vir daardie stemme wat stilgemaak word deur die magte agter tekste. Degenaar (1995:13) vat die saak oor die magte wat in tekstualiteit tot uitdrukking kom, soos volg saam: 'A text is inevitably involved in a discourse which reflects the strategies of control in society. One strategy is to disguise the will to power in the language of truth and knowledge'. Kleingeskiedenisse of kontranarratiewe ${ }^{3}$ word ingeskryf teen meesternarratiewe. Die bedoeling is egter nie om die meesternarratief te vervang met ' $n$ ander meesternarratief nie (Hutcheon 1988:41). Kontranarratiewe is gerig teen die totaliserende en marginaliserende aard van meesternarratiewe, teen die aanspraak op universele waarheid, teen die dominering van ' $n$ gemeenskap deur die elitistiese belangegroep wat baat by die meesternarratief omdat dit hulle magsbasis versterk. Die bedoeling van kontranarratiewe is primêr om te ont-dogma, nie om te vernietig of vervang nie.

* 'n Ander aspek wat in 'n postmodernistiese perspektief 'n belangrike plek inneem, is intertekstualiteit. Dit is veral die insigte van Derrida en sy teorie oor dekonstruksie wat in dié verband 'n groot rol speel. Degenaar (1995:8) verduidelik die siening van intertekstualiteit binne 'n dekonstruksie-paradigma soos volg:

Deconstruction views a text as an intertextual event. In the first place intertextuality refers to the interrelationships between texts in the normal sense of the word 'text' as referring to the interweavings of signs in a book, article or poem. Intertextuality concerns the way in which signs from various books, articles or poems are related to one another. In the second place intertextuality also refers to the interrelationships between texts in the abnormal sense of the word 'text' as referring to any object of understanding. The notion of the interwovenness of signs is kept intact but broadened to include the textuality of all things .... This results in the text losing its assumed fixed identity.

* Die laaste aspek van postmodernisme wat vir hierdie studie van belang is, is parodie. Literatuurteoretici verskil oor die definiëring van parodie (vgl bv Van Heerden 1997:106-108 teenoor Hambidge 1992b:48-50). Breedweg kan gestel word dat parodie nie gesien word as grappige omwerking of nabootsing van 'n ernstige stuk nie (Van Heerden 1997:106), maar as 'repetition with critical distance 
that allows ironic signalling of difference at the very heart of similarity' (Hutcheon 1988:26). Deur parodie vind vervreemding plaas omdat konvensionele norme opgebreek word (Van Heerden 1997:107). Parodie het ten doel om te ontluister en pas perfek in by postmodernistiese strategieë van (onder andere) oordaad en paradokse (Hambidge 1992b:48 dv). Parodie is dus as 'n tipiese literêre vorm wat bevraagteken, kommentarieer en transformeer, tuis in die postmodernistiese idioom.

\subsection{Perspektiewe op kanonisering}

In die jongste tyd word tradisionele standpunte oor die kanonisering van religieuse geskrifte, en meer spesifiek die Ou Testament, al hoe meer bevraagteken (Deist 1995:71). Die siening dat die boeke van byvoorbeeld die Ou Testament reeds gesag gehad het en dat kanonisering bloot beteken het dat die goddelike gesag van die versameling boeke erken is, hou nie meer steek nie. Dit wat deur Foucault op die agenda geplaas is, naamlik die vraag na die belangegroep en magspel ágter gesagvolle literêre werke, kry al hoe meer die aandag. Die oortuiging dat die werklikheid nie gerepresenteer word deur taal nie, laat navorsers ook ten opsigte van kanonvorming vra: Wie praat, en met watter doel? Deist (1995:66-80) het onder andere die volgende uitgewys in verband met die kanonisering van religieuse materiaal:

- lesers met bepaalde belange kanoniseer religieuse geskrifte;

- die motiewe vir kanonisering is nie net religieus van aard nie;

- kanonisering is wesenlik 'n magsgreep waardeur 'n leiergroep hoop om beheer te verkry in 'n toestand van anomie;

- tekste of literatuur wat gekanoniseer is, moet (om die persepsie van eenheid en harmonie te handhaaf) uitgelê en verklaar word;

- 'n kritiese benadering van gekanoniseerde tekste ondergrawe die magsbasis van gemagtigde uitleggers.

Naas hierdie nuwe perspektief op die kanonisering van religieuse tekste, is daar ook in die literatuurwetenskap hernude belangstelling in moderne literêre kanons ${ }^{4}$. In pas met die postmodernistiese idioom word aandag geskenk aan die aard, funksie, plek en legitimiteit van literêre kanons asook die belangegroepe daarby betrokke (Ohlhoff 1993: $58,61)$. 'n Belangrike insig in moderne kanonnavorsing is dat 'n konstante vloei van interpretasies van kanonieke literatuur noodsaaklik is vir die voortsetting van daardie li- 
teratuur se kanonieke status (Fokkema 1993:24). Die belangrike rol van herskrywers (dws uitgewers, kritici, vertalers, samestellers, ens) is ook uitgewys in die navorsing oor moderne literêre kanons. Herskrywers skep bepaalde beelde van skrywers, van literêre werke, tydperke en genres, en is in staat om orspronklike tekste te manipuleer met die oog op ideologiese oorwegings (Ohlhoff 1995:41).

\section{DIE TRAJEK VAN HIERDIE STUDIE}

In die lig van die navorsingsopdrag om voorbeelde van kritiek op aanvaarde en normatiewe geloofsuitsprake binne die Ou Testament na te gaan, wil ek aan die hand van 'n seleksie uit veral dié deel van die Hebreeuse kanon wat bekendstaan as die נביאים, aandui dat inhoudelike spanning in die Ou Testament, sowel as die wordingsgeskiedenis van die $\mathrm{Ou}$ Testament vanuit ' $\mathrm{n}$ ander gesigspunt as die tradisionele, ondersoek kan word. Dit word naamlik gedoen binne die raamwerk van die voorafgaande teoretiese besinning oor die historiese bewussyn, die kontekstualiteit en intertekstualiteit van tekste, meesternarratiewe en kontravertellings, en belangegroepe agter kanonisering. 'n Paar sake moet vooraf opgehelder word:

* Meesternarratiewe staan nie uitgespel in die Ou Testament nie. Meesternarratiewe word geponeer op grond van afleiding. Afleidings word gemaak uit tekste wat die saak (wat as meesternarratief geïdentifiseer is) positief ondersteun, maar veral uit tekste wat polemies gerig is téén die saak. Die sogenaamde Sionsteologie kan byvoorbeeld as 'n meesternarratief geidentifiseer word (vgl Ps 46; 48; 76; 132:1318). Uit die polemiek téén die standpunt dat die tempelberg Sion en daarom ook Jerusalem onineembaar is vanweë $J H W H$ se teenwoordigheid (bv Jer 7:1-15; 26:111; Mig 3:11v) kan onder andere afgelei word dat 'n geloofsuitspraak of belydenis ' $J H W H$ is in Sion', verword het tot 'n politieke heilsideologie wat geen ander oortuiging duld nie.

* Die verhouding tussen meesternarratiewe en kanonisering 5 kan soos volg uiteengesit word: Die ideologiese stramien wat in meesternarratiewe tot uitdrukking kom, speel ' $n$ bepalende rol by die kanonisering van 'nuwe' vertellings/tekste. Gekanoniseerde vertellings/tekste dien op hulle beurt weer as die normatiewe gesagsbron vir die legitimering van aansprake wat in meesternarratiewe verwoord word. Terwyl gekanoniseerde materiaal as beroepsgrond dien vir meesternarratiewe, word daardie selfde materiaal gelees deur die bril van die heersende meesternarratief. 
* Gekanoniseerde literatuur en meesternarratiewe kom daarin ooreen dat albei onder beheer staan van elitistiese herskrywers of leiergroepe. Albei kan ook alleen in sosiale omgewings ontstaan en bly bestaan. Dit beteken dat gekanoniseerde literatuur en meesternarratiewe hulle bestaan te danke het aan die subjektiewe gekontekstualiseerde verstaan en uitleg van sosiale groepe. Omdat sosiale groepe nie konstant bly nie, bly gekanoniseerde literatuur en meesternarratiewe ook nie konstant nie. Gekanoniseerde literatuur is meer konstant as meesternarratiewe in dié sin dat dit selde vervang word, maar na die eis van omstandighede anders uitgelê of aangevul word. Meesternarratiewe daarenteen word ondermyn deur kontranarratiewe wat téén hulle dominerende, totaliserende en marginaliserende aard ingeskryf word. Historiese gebeure kan 'n meesternarratief sy hegemonie as (gepretendeerde) ewig geldende waarheid ontneem, waarmee sy wesenlikste kenmerk verval.

* Kontranarratiewe kan kombineer om 'n nuwe meesternarratief te vorm.

* Finale kanonisering het dit onder andere ten doel om vaste grond te vind deur die diskoers af te sluit en opposisie uit te wis. Dit slaag egter nooit, want teologisering gaan voort. Die ironie is dat ' $\mathrm{n}$ finale kanon vir sy bestaan afhanklik is van die voortgang van daardie diskoers.

* Nie net meesternarratiewe nie, maar ook die religieus-sosiale omgewing word deur navorsers geponeer op grond van afleiding en die sintese van bestaande kennis oor die leefwêreld van tekste. Die saak word egter bemoeilik vanweë die feit dat veral religieus-sosiale groepe nie homogeen is nie.

\section{VOORBEELDE VAN MEESTERNARRATIEWE EN' KONTRANARRA- TIEWE IN DIE נביאים EN AFHANKLIKE LITERATUUR}

\subsection{Hosea}

In die boek Hosea vind ons 'n neerslag van teologisering wat oorspronklik in Israel (die Noordryk) plaasgevind het en later in 'n geringe mate herskryf is in Juda (Breytenbach 1987:732-740). Die meesternarratief wat klaarblyklik teen die middel van die agste eeu vC gegeld het in Israel, was dat Israel die verbondsvolk van $J H W H$ is en dat die heiligdom by Bet-El die sigbare waarborg was vir die voortbestaan van die staat Israel (Am 7:10-13)6. Die noordelike tradisies dat Josef die wettige opvolger van Jakob was 
(vgl Deut 33:13-17; Gen 37:1-11), en dat God aan Jakob die verbondsbeloftes oor 'n groot nageslag en die land by Bet-El gegee het (Gen 28:10-22; 35:1-7) is van die oorlewerings wat hierdie meesternarratief onderbou het.

Kontranarratiewe word in die vorm van 'n familiegeskiedenis en persoonlike ervaring van die profeet teen hierdie meesternarratief ingeskryf: Die ontrouheid van sy vrou en die name van sy kinders word aangebied as kontranarratiewe wat die meesternarratief ondermyn (Hos 1:2-9). Die veel geroemde oorwinning van Jehu oor die dinastie van Agab (2 Kon 9:1-10:28, 30) word beskryf as 'n skanddaad wat om vergelding roep (Hos 1:4v) en die verbondsverhouding word nietig verklaar (Hos 1:9). Die egskeiding van sy vrou (Breytenbach 1996:26-38) word 'n simbool van JHWH se breuk met an oordeel oor die staat Israel (Hos 2:1-12) en sy ongewone optrede teenoor 'n prostituut (Hos 3:1-5; Breytenbach 1979:55-63) proklameer die moontlikheid van 'n vervulling van $J H W H$ se verbondsbeloftes buite die amptelike strukture van staat en kultus om. Die verwagting wat die meesternarratief geskep het, naamlik dat die verbondsverhouding met $J H W H$ by Bet-El herstel word, word afgewys (vgl Hos 6:1-6; 12: 5v, 12v; Breytenbach 1979:116-141; 1985:200-206).

In die herskrywe van genoemde en ander profetiese uitsprake is 'n teks geskep wat die meesternarratief dat die agste-eeuse Israel God se volk is, en dat Hy op grond van sy beloftes hulle sál help, volledig ondermyn. Selfs die geskiedenis wat vertel is om Israel se aanspraak op die verbondsverhouding met $J H W H$ te legitimeer, sowel as die kultus wat daardie aanspraak moes ondersteun, word ontkragtig (vgl Hos 9:1-10:15). Die koning wat in die kultuur van die Ou Nabye Ooste die voortbestaan van die staat moes waarborg, word bespotlik voorgestel (Hos 10:3, 7; 13:10v). Alleen ná die krisis van oordeel en vernietiging is daar, teen alle logika in, die moontlikheid van 'n nuwe begin (Hos 11:8-11; 14:2-9).

Die boek Hosea het klaarblyklik betreklik gou normatiewe gesag verkry (Breytenbach 1987:732-740), na alle waarskynlikheid op grond van die feit dat die staat Israel tot 'n val gekom het soos die profesieë dit voorsien het. 'n Verdere rede sou kon wees dat die veroordeling van konkurerende heiligdomme soos Bet-El, die propageerders van Sion as enigste aanbiddingsplek, soos 'n handskoen gepas het. Met die val van Samaria is die meesternarratief waarteen die profesieë as kontranarratiewe ingeskryf is, vernietig. Die aanspraak dat Bet-El 'n legitieme heiligdom van $J H W H$ is, het egter gebly (2 Kon 17:28). Die boek Hosea is later opgeneem in 'n versameling geskrifte wat gekanoniseer is en wat op hulle beurt kon dien as die beroepsgrond vir ' $n$ nuwe meesternarratief. 


\subsection{Die Sionsteologie}

Die Sionsteologie kan gedefinieer word as:

A current of thoughts, most noticable in the religious traditions of the Southern Kingdom of pre- to post-exilic times, in which Jerusalem played a major role as the symbol of Yahweh's presence among his people. Jerusalem accordingly was viewed as the centre of all true Yahwism, inconquerable and symbol, too, of the coming Messianic age.

(Deist 1984:189)

In die Ou-Testamentiese geskrifte word die aanspraak dat $J H W H$ Jerusalem-Sion gekies het as sy ewige woonplek, onder andere gelegitimeer met 'n vertelling wat die heiligdom en priesterskap verbind met optrede van die aartsvader Abram (Gen 14:17-20). Dit staan kennelik teenoor noordelike aansprake wat die heiligdom by Bet-El gelegitimeer het met vertellings oor die 'noordelike' aartsvader Jakob (Gen 28:10-22; 35:115). Albei dié heiligdomme het as staatsheiligdomme van die twee ryke gefunksioneer. By albei was die afstaan van tiendes as 'n vorm van belasting dus belangrik (Gen $14: 20 ; 28: 22)$.

Die aanspraak dat Sion die ware tuiste van $J H W H$ is, het aanvanklik deel gevorm van die stryd tussen die twee politieke entiteite Israel en Juda. Dawid en ook Salomo na hom het klaarblyklik gehoop dat die vestiging van 'n paleis en staatsheiligdom op neutrale terrein (2 Sam 5:6-16) die stryd tussen Israel en Juda sou help besleg en dat die nuwe heiligdom wat die bestaan van die personale unie Israel-Juda moes waarborg, 'n simbool van eenheid sou word. As gevolg van die beleid van Salomo het die personale unie egter ná sy dood verbrokkel (1 Kon 12:1-20), en het Sion staatsheiligdom van slegs Juda gebly. In Israel is daar onmiddellik aandag gegee aan die vestiging van 'n eie staatsheiligdom. Aanvanklik is Sigem en Pniël vermoedelik gekies vanweë die ou tradisies verbonde aan dié twee kultusplekke (Gen 12:6; 32:31), maar uiteindelik het Bet-El die status van staatsheiligdom gekry en behou (1 Kon 12:25-13:34).

Die vaste oortuiging dat Sion die enigste ware heiligdom van $J H W H$ is en daarom oninneembaar, het nie net gegroei uit die feit dat dit 'n staatsheiligdom was nie, maar veral uit die feit dat daar kort nadat Bet-El as konkurrent uitgeskakel is, stappe geneem is om ander heiligdomme in Juda te sluit (2 Kon 18:1-4). Dit was 'n vorm van kanonisering met al die elemente van 'n elitistiese groep wat deur 'n magsgreep die diskoers oor wie die ware God is en waar Hy woon, wou beeïndig. Hierdie kanonisering is vooraf, maar veral ná die tyd gerugsteun deur liturgiese tekste (waarskynlik van die- 
selfde aard as Ps 46; 48; 76; 78:56-69); deur narratiewe oor die korrupsie by konkurrerende heiligdomme soos Bet-El (vgl bv 1 Kon 12:28-13:34; Hos 5:1-4; Am 7:10-17); deur narratiewe oor die permanente Dawidiese koningskap in Jerusalem (vgl 2 Sam 7: 8-29) en in besonder deur narratiewe oor die legendariese redding van Jerusalem (vgl 2 Kon 18:13-19:37; Jes 36:1-37:38). Hierdie kanonisering van Jerusalem het egter nie die diskoers beeïndig nie (vgl 2 Kon 21:3-9).

'n Verdere poging tot kanonisering in die tyd van Josia was meer geslaag, want hierdie keer is dit ook nog gerugsteun deur 'n wetboek wat teruggevoer is na Moses, die vestiger van die Israelitiese godsdiens (vgl Deut 12; 2 Kon 22:3-23:20 - let veral op die 'finale' afrekening met Bet-El). Die Sionsteologie het juis in die tyd van Josia en kort daarna een van sy tydperke van hoogbloei beleef. As meesternarratief het die Sionsteologie 'n konsentrasie van mag in Jerusalem meegebring en gelegitimeer. Die instansies wat baat gevind het by hierdie meesternarratief, was die koningshuis en tempelpersoneel. Die pogings om opposisie te marginaliseer en stil te maak, kom dan ook uit dié geledere (vgl Jer 11:18-12:6; 18:18-23; 36:5, 19, 26; 37:11-38:13).

Die Sionsteologie is uit profetiese kringe ondermyn. Kontranarratiewe uit dié kring is gerig teen die oortuiging dat $J H W H$ Hom deur sy beloftes op so 'n wyse verbind het aan die Sionsberg en aan die behoud van die Dawidiese dinastie, dat Hy nie anders kon nie as om Jerusalem te beskerm. Dit was dus gerig teen die Sionsteologie se inperking van die soewereiniteit van $J H W H$.

\subsection{Voorbeelde van kontranarratiewe teen die Sionsteologie}

\subsubsection{Jeremia}

In die boek Jeremia vind ons die neerslag van profetiese verkondiging wat die dwaasheid dat daar 'n organiese band tussen $J H W H$ en Sion is (Van Selms 1980:114, 128) en dat die verbondsbeloftes sal geld sonder dat die verbondsverpligtinge nagekom word, aan die kaak stel (Jer 5:1-17, 20-30; 6:1-7:15; 8:18-9:22, ens). Die oortuiging dat $J H W H$ teen alles in aan sy beloftes gehou kan word, was 'n miskenning van sy soewereiniteit. Daarteenoor stel die profetiese verkondiging dat $J H W H$ vrymagtig is 'om naar bevind van omstandigheden met zijn volk te handelen, zonder gebonden te zijn aan zijn uitgesproken ... bedoelingen (Van Selms 1980:240; vgl Jer 18:1-10; 45:1-5).

In die boek Jeremia word die beeld van die koning afgetakel (vgl Jer 22:1-19, $24: 30 ; 24: 8-10 ; 34: 1-22 ; 36: 1-32$ ). Die koning van Jerusalem word nie net voorgehou as selfsugtig, onregverdig en goddeloos nie, maar ook as 'n magtelose lafaard (Jer 38:14-28). Dieselfde geld min of meer vir die priesters en profete van Jerusalem (Jer 19:14-20:6; 23:9-40; 28:1-17). Daarmee word die elitistiese groep wat draers was van en gebaat het by die meesternarratief oor die oninneembaarheid van Jerusalem, ontmasker as vals, onbetroubaar en skurkagtig. 
Die meesternarratief oor die oninneembaarheid van Sion is vernietig deur die historiese gebeure van $586 \mathrm{vC}$ en daarna (Jer 52:1-30). Daarmee is die oortuiging dat Sion die enigste ware aanbiddingsplek van $J H W H$ is, egter nie vernietig nie, want daar word in die boek Jeremia ' $n$ moontlikheid van herstel voorsien vir Israel en Juda ná die krisis (Jer 30:1-33:13). In dié nuwe era sal 'n koning uit die geslag van Dawid wat regverdig regeer volgens die wil van $J H W H$, op die troon wees (Jer 23:1-6; 33:14-26).

Deur die oordeelsprofesieë teen die vyande van Juda, en in die besonder dié teen Babel, voor te hou as die profeet Jeremia se finale woord (Jer 46:1-51:64), het die herskrywers van die weergawe van die boek Jeremia in die Hebreeuse kanon, die beeld van herstel ná die krisis versterk (vgl die plasing van die profesieë teen vreemde volke in die Septuaginta-uitgawe van die boek Jeremia). In hierdie vorm word die boek in die tyd van die Babiloniese ballingskap en daarna die beroepsgrond vir ' $n$ nuwe meesternarratief.

\subsubsection{Miga 2-5}

Die boek Miga bied een van die treffendste voorbeelde van meesternarratief en kontranarratief wat saam in een enkele gekanoniseerde werk opgeneem is. Die oortuiging dat Jerusalem oninneembaar is, word naamlik as betroubare waarheid voorgehou én as vals verwerp. Binne 'n Westerse verstaanshorison bied dié naasmekaar plaas van inhoudelik totale teenstrydighede, ernstige probleme. Die maklikste uitweg uit die dilemma is natuurlik om die integriteit van die teks te betwyfel. Dit is inderdaad deur verskillende geleerdes gedoen (vgl Van der Woude 1976:11). Van der Woude het egter op goeie gronde aangetoon dat Miga 2-5 verstaan kan word as 'n vorm van wat genoem word 'dogmadiskussie'. Só verstaan kom verdedigers van die meesternarratief dat Sion oninneembaar is $(2: 11 \mathrm{c}-13 ; 4: 1-9,11-13 ; 5: 4-5,7-14)$ te staan teenoor profetiese uitsprake oor die komende vernietiging van Jerusalem en die herstel wat eers ná die krisis moontlik is $(2: 1-5,6-11 b ; 3: 1-12 ; 4: 10 ; 4: 15-5: 3 ; 5: 6)$, Van die verdedigers van die Sionsteologie sê Van der Woude (1976:162v).

[A]lgemeen geldende theologoumena zijn de basis voor een heilszekerheid die in objectieve garantie ontaard is en daarom zonder enige dialectiek nationalistisch-religieus kon functioneren. Hier gold: $Y H W H$-berg Sion-Jeruzalem, een drievoudige snoer dat niet verbroken word! Daarom waren Micha's opponenten ook gerust: wanneer de volken komen om Jeruzalem te belegeren, zal dat de ondergang van de volken betekenen. Rechtlijnig geredeneerd kon niets anders gebeuren: $Y H W H$, hun koning, was immers in hun midden (vgl 3:11; 4:9)! 


\title{
Daarteenoor is
}

\begin{abstract}
Micha's prediking ... een gloeiend protest tegen een in zich gekeerde, zelfgenoegzame en versteende orthodoxie die de triomf der genade hoog in het vaandel geschreven heeft, maar in de praktijk van het leven niet pal staat voor recht en gerechtigheid. Het gericht komt over allen die God wel, maar zichzelf niet aan zijn woord houden (Van der Woude 1976:12).
\end{abstract}

Die verdedigers van die Sionsteologie se woorde toon noue verband met gedeeltes soos Psalm 46; 48; 76; Jesaja 17; Joël 2 en Sagaria 12 (Van der Woude 1976:160). Van der Woude (1976:180-182) dui ook aan dat van die gedeeltes waarin die Sionsteologie verdedig word, nóu aansluit by en waarskynlik 'n vrye aanhaling is van gedeeltes uit Jesaja 2. Dit beteken dat gekanoniseerde profetewoorde in 'n nuwe konteks die tekstuele argument kan wees vir 'n meesternarratief soos die Sionsteologie. Dit beteken egter ook dat die verdedigers van die Sionsteologie (en in Miga 2-5 het hulle die laaste woord!) se woorde gekanoniseer kan word as Godswoord, of soos Van der Woude (1976:190) dit stel: 'Ook de heilswaarheid is als werkelijke, effectieve, heilbrengende waarheid aan uur en tijd gebonden. Daarom kunnen pseudo-profeten woorden van Schriftprofeten misbruiken, maar kunnen pseudo-profetische teksten ook tot canonieke Schrift worden'.

Die boek Miga is nieteenstaande al sy teenstrydighede en verstaansprobleme gekanoniseer. In watter mate daar aanvulling was deur herskrywers, kan nie meer met sekerheid vasgestel word nie. Wat wel seker is, is dat die boek in die tyd na die Babiloniese ballingskap 'n rol gespeel het in die opbou van 'n nuwe meesternarratief.

\subsubsection{Die boeke 1 en 2 Samuel en 1 en 2 Konings}

Die boeke 1 en 2 Samuel en 1 en 2 Konings het 'n baie ingewikkelde ontstaansgeskiedenis. Dit is duidelik dat verskillende tradisies uit verskillende sosiale kringe in Israel en Juda hulle weg gevind het na hierdie magistrale werk. Daar is redelike eenstemmigheid onder geleerdes dat hierdie tradisies binne sogenaamde Deuteronomistiese kringe hulle finale vorm gekry het na minstens twee herskrywings, waarvan die laaste tydens die Babiloniese ballingskap. Eynikel (1996:357-364) het byvoorbeeld in sy navorsing oor 1 en 2 Konings tot die volgende gevolgtrekking gekom: Daar was drie redaksio- 
nele bewerkings van die materiaal wat uiteindelik die Koningsboeke geword het. Die eerste redaksionele bewerking van ouer materiaal het kort na die dood van Hiskia plaasgevind, die tweede (uit die kring van die Deuteronomiste) net na die dood van Josia, en die derde (ook Deuteronomisties) gedurende die Babiloniese ballingskap.

Selfs indien die wordingsgeskiedenis nie presies só verloop het nie, is dit nogtans duidelik dat literatuur wat binne 'n bepaalde religieus-sosiale kring (naamlik die Deuteronomistiese) gesag verkry het, behou is, en dat wysiging wat in nuwe omstandighede vereis word (vgl die situasie voor en na $586 \mathrm{vC}$ ) plaasgevind het deur aanvulling. Hierdie aanvulling en herskrywing het vanselfsprekend inhoudelike spanning meegebring. 'n Bekende voorbeeld uit die Samuelboeke is die vraag of die koningskap $J H W H$ se wil was of nie ( $\mathrm{vgl} 2$ Sam $8 \& 9$ ). In hulle finale vorm is daar in die Samuel- en Koningsboeke egter duidelike tendense aanwysbaar wat vir hierdie ondersoek van belang is. Die koning en priester word naamlik 'uitgeskryf' en die profeet word 'ingeskryf'.

Die teologiese program wat in die lied van Hanna aangebied word, lê sterk klem op die absolute soewereiniteit van $J H W H$ (1 Sam 2:1-10). Die vertellings in 1 en 2 Samuel bied 'n dramatiese illustrasie daarvan dat $J H W H$ geringes verhoog (Peninna, Hanna, Samuel, Saul, Dawid) en hooghartiges verneder (Hofni en Pinehas, Saul, Dawid; vgl Loader 1975:191v). In die loop van die vertelling word die figuur van die koning op ' $n$ baie subtiele wyse geparodieer: Die koning (Saul en Dawid) ontbloot sy skaamdele terwyl hy in 'n toestand van ekstase is (1 Sam 19:24; 2 Sam 6:14-16, 20). Saul is 'n patetiese figuur wat op 'n bedenklike manier hulp soek by 'n afgestorwe profeet (1 Sam 28). Dawid bly tuis wanneer ander konings hulle plig doen op die slagveld, hy is lui, onbetroubaar, onderduims en laat sy trouste ondersteuner vir eie gewin vermoor (2 Sam 11). Hy bring ook 'n ramp oor sy onderdane (2 Sam 24:1-5).

Dieselfde tendens word in die Koningsboeke aangetref: In sy laaste dae is Dawid 'n magtelose ou man wat uitgelewer is aan familie-intriges (1 Kon 1). Salomo, die geliefde van $J H W H$ (2 Sam 12:24v) wat wêreldroem verwerf het (1 Kon 10:23-25) rig aanbiddingsplekke in vir afgode (1 Kon 11:6-8) en vervreem sy onderdane deur dwangarbeid (1 Kon 11:28; 12:4). Hierdie ontluistering word veral in die Elia-Elisa legendes voortgesit: Die koning staan weerloos teen die profetewoord (1 Kon 17:1; 18:1-9), hy is 'n swakkeling en 'n knoeier ( 1 Kon 21:1-16; 22:30vv), 'n naamlose, patetiese figuur (2 Kon 5:6; 6:26v; 7:12). Wat opmerklik is, is dat daar op enkele uitsonderings na, telkens ' $n$ profeet of profete in die omgewing van die koning is wanneer hy uitgeskryf word, en dat die profeet telkens voorgehou word as die standvastige figuur wat sekerheid het oor die toekoms. 
Die priester en kultuspersoneel word ook op 'n subtiele wyse uitgeskryf in die Samuel- en Koningsboeke. Samuel word as priester opgelei, maar is eintlik ' $n$ profeet (vgl 1 Sam 2:18 en 19 waar die priesterlike drag, naamlik die linneskouerkleed 'vervang' word met die mantel van die profeet; vgl ook 1 Sam 9:6-10:16; 28:14). Dit is as profeet dat Samuel roem verwerf in Israel (1 Sam 3, vgl vs 19v). Daarteenoor is die priester Eli 'n magtelose figuur en sy twee seuns opperste niksnutte wie se optrede die volk vervreem van $J H W H$ (1 Sam 2:12-17, 22-15; 3:13). Die priester en sy leerlinge roep die oordeel van $J H W H$ op (1 Sam 2:27-3:18). Hulle is indirek verantwoordelik vir die verlies van die verbondsark, die simbool van $J H W H$ se teenwoordigheid by Israel (1 Sam 4:1-22). Die naamlose priester het nie toegang tot God nie (1 Sam 14:36 v). Priesters speel ' $n$ ondergeskikte rol by die bou en inwyding van die tempel. Die tempel word gebou deur dié een wat deur die profeet daarvoor aangewys is (1 Kon 6:137; 8:1-66). Priesters word geassosieer met valse godsdiens (1 Kon 12:31 v; 2 Kon 17: 27-33). In die Elia-Elisa legendes word die taak van die priester oorgeneem deur die profeet (1 Kon 18:30-39; 2 Kon 5:8v, 13-18). Selfs by die verklaring van die inhoud van die wetboek wat uit-en-uit 'n priesterlike funksie is, word die hulp van 'n profeet ingeroep (2 Kon 22:11-19). Alhoewel daar ook enkele goeie priesters was (2 Kon 12: 2 ), word die rede vir die ondergang van Israel en Juda vierkantig voor die deur van die verworde kultus gelê (2 Kon 17:7-23).

Naas die reeds genoemde ophemeling van die profeet teenoor koning en priester, is daar ook nog in die Samuel- en Koningsboeke 'n oormaat van voorbeelde om te illustreer dat profete $J H W H$ se ware dienaars is wat direkte toegang het tot Hom en wie se woorde absoluut betroubaar is omdat $J H W H$ dit nooit onvervul laat nie (1 Sam 16:1-3; 2 Sam 12:7-12; 1 Kon 21:17-19; 11:38; 2 Kon 13:13, 23 ens). Die profeet kan selfs lewe en dood gebied ( 2 Kon 4:8-37; 2:23-25).

\section{4 'n Nuwe meesternarratief}

Soos reeds aangedui is die meesternarratief oor die oninneembaarheid van Sion vanweë $J H W H$ se teenwoordigheid, vernietig deur die gebeure in $586 \mathrm{vC}$. Deur die herskrywing van die Samuel- en Koningsboeke sowel as die profetiese geskrifte wat tóé reeds bestaan het, is daar antwoorde en sin gesoek in die nuwe situasie van die ballingskap. 'n Paar sake het vasgestaan: Dié instellings wat die voortbestaan van Juda moes verseker, naamlik koningskap en kultus, het jammerlik gefaal. Die profete van $J H W H$ se woorde oor Jerusalem en die krisis wat op hande was, is bewaarheid. Daarmee het die status van profete en profesieë dramaties gestyg. Dit is presies die perspektief wat in die Samuel- en Koningsboeke in hulle finale vorm na vore kom. Die hoop vir die toekoms lê by die gesaghebbende profetewoord! Of die heilsverwagting in profeteboeke 
soos Jesaja 1-39, Jeremia, Hosea, Amos en Miga deur die profete self of deur herskrywers in die tyd van die ballingskap te boek gestel is, is vir hierdie studie nie van wesenlike belang nie (vgl Jeremias 1996:67-85 vir 'n bespreking van eskatologiese gedeeltes in Hosea). Wat wel van belang is en met stellige sekerheid beweer kan word, is dat die profeteboeke as gesaghebbende Godswoord 'n nuwe meesternarratief help vestig het: $J H W H$ sou (moes) vir die oorblyfsel van sy volk in ballingskap 'n nuwe toekoms skep waarin 'n gesalfde uit die geslag van Dawid 'n belangrike rol sou speel. JHWH sou (moes) sy volk se vyande vernietig. Die volk moes net die verbondsverpligtinge sorgvuldig nakom om 'n herhaling van die vorige katastrofe te voorkom. Waar die oninneembaarheid van Sion in die tyd voor die ballingskap die dominante was, het dit in die tyd na die ballingskap verskuif na die heil van die gemeenskap van gelowiges in Jerusalem. Die vernietiging van die vyande was 'n belangrike voorwaarde vir die aanbreek van die heilstyd.

Die nakoming van die wet en suiwere diens van $J H W H$ het die nuwe legitimering van die volk van God geword. Dit is onder andere gestel teenoor Judeërs wat nie weggevoer is in ballingskap nie en wat hulle aanspraak op die besit van die land begrond het met die belofte aan Abraham (vgl Eseg 33:23-26). Die kanonisering van die Wet van Moses in Jerusalem ná die ballingskap hou ook hiermee verband. By hulle terugkeer uit Babilonië is die oorspronklike elitistiese Judese minderheid se nageslag gekonfronteer deur die oorspronklike armer Judeërs se nageslag wat intussen die grondbesitters geword het (Eseg 11:14-21). Deist (1995:72) sien die saak so:

It is understandable that, in such circumstances, the question would have arisen as to who really constituted the 'people of God': those who had not been rejected by the land of the fathers, or those who had been obeying the Law of Moses all these years .... In the end the elite returnees' definition of Jewish identity, their idea of the true 'people of God' ... their priestly line and concept of religious orthodoxy prevailed.

Die kanonisering van die Wet van Moses (Neh 8:1-4; 9:38-10:39) het nie net die elitistiese groep se aanspraak dat hulle die volk van God is, begrond nie; dit het ook hulle marginalisering van opponente gelegitimeer (vgl Esra 10; Neh 13). Dit was kennelik 'n magsgreep, of soos Deist (1995:73) dit stel: 
What leads to the canonisation of a book are the views propagated in it, especially if these views are useful in legitimising particular solutions to problems of power contemporaneous with the promulgation of that canon. It remains true, of course, that the popularity of a particular book contributes to its inclusion in a canon. The critical question is, however, popular among whom?

\subsection{Reaksies op die nuwe meesternarratief}

\subsubsection{Die na-eksiliese profete}

Die na-eksiliese profeteboeke kan verstaan word teen die agtergrond van hierdie nuwe meesternarratief. $J H W H$ se oordeel oor die vyande van die Godsvolk wat beskerming in Sion soek, is byvoorbeeld die hoofsaak in die boek Obadja. Haggai sluit aan by die Sionsteologie van die voor-eksiliese tyd (Hag 2:10; vgl Van der Woude 1982:16), maar roep, in ooreenstemming met die nuwe meesternarratief, die lesers op tot 'n nuwe gehoorsaamheid aan $J H W H$ om onder andere deur die herbou van die tempel, die heilstyd te verwesenlik. Sagaria verkondig dat God besig is met Sion: 'De het Godsvolk bedreigende wereldmacht zal door de legerscharen van $Y H W H$ worden uitgeschakeld .... Sion zal overeenkomstig de eeuwenlang aan de Godsberg gehechte traditie het middelpunt van het heilige land en de wereld zijn, door Gods voorzienige zorg beschut (Van der Woude 1984:15).

Alhoewel daar klemverskille is en 'n mens nie te haastig moet oordeel oor die uitsprake van na-eksiliese profete nie (Van der Woude 1984:15v), is dit duidelik dat die nuwe Sionsteologie met sy kombinasie van wetsonderhouding en. $J H W H$ se vernietiging van die vyande, selfversekerdheid kon laat gedy. Daar was egter ook reaksie van 'n ander aard op die nuwe meesternarratief.

\subsubsection{Jona}

In die vertelling van die boek Jona word die meesternarratief op 'n besondere wyse ondermyn.

Holbert (1996:334-354) meen dat ons in die boek Jona 'n satire het. Die vraag of die boek Jona ' $n$ satire is of nie, hang natuurlik alles af van die vraag hoe 'n mens satire definieer. Dit is duidelik dat Jona nie as 'n satire gelees kan word as die definisie van Grové (1982:109) as vertrekpunt geld nie, naamlik 'n literêre werk waarin die dwaashede en wanpraktyke van die mens aan die kaak gestel word en wel op so 'n wyse dat die lag van die "reggeaarde" gemeenskap by die blootlegging van die euwel opgewek word'. Holbert (1996:339) definieer 'n satire soos volg: 
* Satire is humor based on the fantastique, the grotesque, the absurd.

* Satire has a definite target which must be familiar enough to make the assault meaningful and memorable.

* Satire is characterized by indirection of attack. The charge comes from the flanks rather than head-on.

* Satire pillories inferior excesses; hypocrisy is one classic and familiar example.

* Satire is usually external in viewpoint. The actions of the character or the overt effects of the satirized idea are emphasized rather than the interior realm of the individual or idea.

Holbert lees die boek Jona dan in die lig van sy definisie as 'n satire.

Die boek sou egter ook as ' $n$ parodie gelees kon word. Naas die hiperboliese (vgl bv 1:4-16; Holbert 1996:342v) figureer die paradoksale baie sterk in die vertelling. JHWH roep Jona om op te staan (קום), maar hy gaan so ver as moontlik af (ירד). Nineve lê oos, maar Jona vlug wes, ensovoorts. Die profeet word op dié wyse geparodieer. Veral die kontrastering van die profeet se optrede met dié van die heidene (Jona $1: 5-16 ; 3: 3-4: 2)$ en die kontrastering van sy oortuigings en gesindheid met dié van $J H W H(4: 1-11)$ ontluister die profeet. Die vertelling bring by die leser vervreemding. Konvensionele norme word verbreek met betrekking tot ware profete van $J H W H$ en die absolute sekerheid oor die uitkoms van profesieë soos gepropageer in die Samuel- en Koningsboeke en soos weergegee in die boek Jeremia. Die weiering van $\mathrm{JHWH}$ om sy profeet se woord waar te maak is 'n bevraagtekening van en kritiese kommentaar op die meesternarratief wat die oordeel van $J H W H$ oor sy volk se vyande hoog op die agenda gehad het. Trouens, die meesternarratief wat as sodanig gelegitimeer is deur gekanoniseerde profeteboeke (Samuel en Konings) en profetewoorde (Hosea, Amos, Jeremia, ens), word ondermyn deur die parodiëring van profeet en profesie. Op hierdie wyse is die verhaal van Jona 'n kontranarratief wat ingeskryf word teen die na-eksiliese Sionsteologie, en word $J H W H$ se absolute soewereiniteit ook ten opsigte van die uitkoms van profesieë gehandhaaf.

Die feit dat die boek Jona opgeneem is in dieselfde kanon as die boek Obadja, en dat in sowel die Hebreeuse as Alexandrynse kanons dié twee boeke bymekaar gegroepeer is (Breytenbach 1983:139v), bevestig die waarneming wat reeds gemaak is: Gekanoniseerde literatuur word nie in nuwe omstandighede opgehef nie, maar aangevul, al is dit dan ook deur kontranarratiewe. 


\subsubsection{1 \& 2 Kronieke}

Die boeke 1 en 2 Kronieke verteenwoordig 'n andersoortige reaksie op die meesternarratief van die na-eksiliese gemeenskap in Jerusalem. Kronieke is as positiewe onderskrywing van die Sionsteologie 'n sprekende voorbeeld van wat Jeismann (1985:14) noem 'Legitimierung von Zuständen oder Aussprüchen' deur hervertelling van die geskiedenis. In die nuwe meesternarratief het die kultus en die messiaanse koning 'n sentrale plek ingeneem. Dit is begryplik want die elitistiese groep wat gebaat het by die meesternarratief was kultuspersoneel in en om die herboude tempel in Jerusalem. Daar was egter een groot probleem: Gekanoniseerde vertellings oor die geskiedenis van die volk van God in die Samuel- en Koningsboeke het koning en priester uitgeskryf. Die geskiedenis moes dus radikaal herskryf word om die figuur van koning en priester in ere te herstel en om ander aansprake oor die regmatige erfgename van die priesterskap in Jerusalem te legitimeer (vgl Cross 1973:195-215 vir 'n bespreking van priesterlike genealogieë). Die hervertelling in Kronieke verskil in baie opsigte van dié in die brongeskrifte Samuel en Konings. Die volgende is ' $n$ paar voorbeelde daarvan: Dawid dans nie met sy skaamdele ontbloot voor die ark nie (2 Sam 6:14-20), maar in volle priesterlike ornaat (1 Kron 15:27). Sy egbreuk en die moord op Uria word gewoon verswyg en hy tree na vore as die vestiger van die kultus in Jerusalem (1 Kron 21:22-25:31; 28:1-29:9). Anders as in die Samuel- en Koningsboeke vind wonderwerke nie in die eerste plek in die omgewing van profete plaas nie, maar in die omgewing van die tempel waar priesters is (bv 2 Kron 26:16-21; 32:20). Hierdie voorbeelde van legitimering deur herskrywing in die Kroniekboeke kan tienvoudig vermeerder word. Tegelyk word aansprake teenoor ander religieuse groepe in die tyd van die herskrywers ook gelegitimeer. Die aanspraak van die groep wat tydens die ballingskap in Jerusalem kultiese rituele in stand gehou het, en die aanspraak van diegene wat nie in ballingskap weggevoer is nie dat húlle draers van die beloftes aan Abraham is (Eseg $11: 14-21$; 33:23-26), word op 'n besondere wyse hanteer: Naas die genealogiese lyste wat die teruggekeerde ballinge 'aanwys' as die ware erfgename, word daar gewoon ontken dat enige iemand van die volk van God met die wegvoering in Jerusalem of Juda agtergebly het (2 Kron 36:17-20; vgl daarteenoor 2 Kon 25:12).

Die feit dat die boeke 1 en 2 Kronieke saam met Samuel en Konings in die finale kanon opgeneem is, al het dit, te oordeel aan die posisie van Kronieke in die Hebreeuse kanon, betreklik laat gebeur, is 'n bevestiging van die tendens wat nou reeds telkens uitgewys is: Gekanoniseerde literatuur word nie vervang nie, maar aangevul.

\section{FINALE KANONISERING, HERSKRYWING EN AANVULLING}

Die finale kanonisering van die Hebreeuse heilige geskrifte is volgens Deist gestimuleer deur die vernietiging van die tempel en die Joods-Christelike kontrovers. Die bedoe- 
ling was klaarblyklik om in ' $n$ toestand van anomie die Joodse identiteit en waardesisteem te probeer handhaaf (Deist 1995:6v). Soos in ander gevalle het ook finale kanonisering egter nie die diskoers beeïndig nie. Trouens, die proses van interpretasie wat sou uitloop op aanvulling van die gefinaliseerde kanon, was reeds voluit aan die gang. Hierdie proses, wat vanselfsprekend verskillende trajekte gevolg het in verskillende geloofsgemeenskappe (naamlik die Judaïstiese en Christelike) het uitgeloop op verskillende aanvullings van die kanon in die vorm van die Talmoed en die Nuwe Testament - laasgenoemde as kontranarratief teen wettisisme en die inperking van God se genade, en eersgenoemde as positiewe onderskrywing daarvan.

Binne die Joodse gemeenskap kan die Qumran-geskrifte ook as 'n kontranarratief teen die meesternarratief van Jerusalem beskou word. Daar het egter al vroeër reeds binne die Judaïsme verskillende herskrywings van die gekanoniseerde geskrifte plaasgevind: Die herskrywing wat binne die religieus-sosiale omgewing van elitistiese groepe in Jerusalem plaasgevind het, weerspieël in die volgorde van boeke in 'n hoë mate die historiese proses van aanvulling (vgl die volgorde Wet, Profete, Geskrifte, asook Kronieke as laaste van die boeke). Daarteenoor het die herskrywing in Joods-Hellenistiese kringe, met 'n volgorde van boeke wat volgens die skema verlede-hede-toekoms gerangskik is, 'n sterker interpretatiewe aard. Hierdie volgorde beteken onder andere dat die Skrifprofete voorspellings is wat oor die toekoms handel.

Die herskrywing en aanvulling van die kanon in die tyd van die Reformasie is ' $n$ studie op sy eie. Die volgende voorlopige opmerkings kan wel gemaak word: Die slagspreuke sola scriptura en ad fontes verwoord kontranarratiewe wat aanvanklik ingeskryf is teen die meesternarratief van die elitistiese magsgroep in Rome dat húlle die ware interpreteerders van die kanon is en kennis beheer. Hierdie kontranarratiewe het egter 'n dramatiese invloed gehad op die herskrywing van die kanon in Reformatoriese kringe. Die keuse vir 'oorspronklike' geskrifte as kanon teenoor die vertaalde geskrifte van die Roomse kerk, het meegebring dat slegs dié boeke van die Ou Testament wat in hulle Hebreeuse en Aramese vorm beskikbaar was, in die kanon opgeneem is. Daarmee is die boeke van die Joodse kanon gekies. Die volgorde van boeke in die vroeg-Christelike (dit wil sê Joods-Hellenistiese) kanon is egter behou. Dit het onder andere beteken dat die interpretasie van die Ou Testament, en in die besonder van die profeteboeke, as beloftes vir die toekoms wat in Jesus Christus sou aanbreek, gehandhaaf is. In die gees van die Reformasie om kennis en inligting te demokratiseer, is die gekose kanon verder herskryf in die vorm van vertalings.

\section{BELYDENIS, BELYDENISSKRIFTE EN KANONISERING}

' $n$ Belydenis in die sin van 'n 'plegtige verklaring van geloof' (Odendal et al 1994:73) is wesenlik ' $n$ eksistensiële kleingeskiedenis wat meestal bedoel is as 'n kontranarratief. 
Die belydenis 'Jesus is die Kurios' kry eers werklik reliëf wanneer dit verstaan word teen die agtergrond van die meesternarratief dat die Romeinse keiser 'n goddelike figuur en kurios is.

Die Nederlandse Geloofsbelydenis (NGB) is ook 'n goeie voorbeeld van so 'n eksistensiële geloofsuitspraak wat bedoel was as kontranarratief teen die meesternarratief van Rome. Hierdie meesternarratief waarvolgens Rome oor die waarheid beskik het, het onder andere gedien as legitimering vir die grootskaalse marginalisering van Protestante (vgl NHKA 1987:126-132). Belydenisse, dit wil sê kontranarratiewe soos die NGB, verkry by aanvaarding in 'n wyer religieus-sosiale kring egter 'n status wat dit gewoonlik met ander kontranarratiewe soos die Heidelbergse Kategismus (HK) laat kombineer om uiteindelik ' $n$ nuwe meesternarratief te help vestig en onderbou. Tydens die Reformasie is hierdie proses voltooi by die Nasionale Sinode van Dordrecht in 1619. Die NGB, HK en besluite van die Nasionale Sinode is gekanoniseer. Ook hier het gegeld: 'literary canons are created during periods of crisis to prevent, curb or reverse a situation of anomie in a particular group in order to retain or restore its 'identity and value system' (Deist 1995:69). Mede vanweë die kanonisering het die NGB daarna al hoe minder as eksistensiële belydenis van geloof en al hoe meer as finale kanon gefunksioneer om binne die raamwerk van 'n nuwe meesternarratief (in die vorm van die Ortodoksie) opposisie te marginaliseer.

\section{GEVOLGTREKKING}

Die teoretiese besinning oor die funksie van die historiese bewussyn, kontekstualiteit en intertekstualiteit, meesternarratiewe en kontranarratiewe, en kanonisering, bied 'n nuwe perspektief op sake soos kritiek teen aanvaarde normatiewe uitsprake en teenstrydighede in die Ou Testament.

Die Ou Testament het as tekensisteem of verslag oor gekontekstualiseerde verstaan oor ' $\mathrm{n}$ tydperk van meer as duisend jaar ontstaan. Dit is maar deel van ' $\mathrm{n}$ nimmereindigende proses van interpretasie van gesagvolle tekste in nuwe omstandighede. Indien hierdie interpretasie of verstaan aangebied word in die vorm van kontranarratiewe, loop dit gewoonlik uit op aanvulling van die gesagvolle literatuur. Die vraag hóé gesagvolle literatuur uitgelê en aangevul word, hang ten nouste saam met die meesternarratief wat in die bepaalde omstandighede geld in die religieus-sosiale gemeenskap.

Daar is ' $n$ ironiese aspek verbonde aan die finale kanonisering van tekste. Soos aangedui kan 'n kanon nie status in 'n gemeenskap behou tensy dit telkens gelees, dit wil sê geïnterpreteer word in die besondere omstandighede waarin die gemeenskap hom bevind nie. Anders gestel: religieuse gekanoniseerde literatuur kan nie bestaan sonder 
teologisering nie. Teologisering of interpretasie lei altyd tot een of ander vorm van aanvulling, dit wil sê herskrywing en dus verandering van die gekanoniseerde literatuur. Die vraag of die aanvulling in een bundel met die bestaande kanon geskied of nie, is slegs van belang in soverre aparte aanvulling wel soms vervang word.

Die aard van die proses wat op kanonisering uitloop, hou in dat daar onvermydelik inhoudelike spanning en teëspraak in gekanoniseerde tekste sal wees. Teologisering op grond van die gekanoniseerde tekste sal, in die lig daarvan dat dit gekontekstualiseerde verstaan is, nog meer uiteenlopend van aard wees. 'n Wesenlike vraag in dié verband, is of die spreke oor God (teologisering) daarop gerig is om God in te trek in diens van die eie belang.

\section{RIGLYNE VIR 'N EIETYDSE TEOLOGISERING}

Elke uitspraak oor God en sy handeling met mense is gekontekstualiseer. Dit geld vir sowel die finale kanon (Ou- en Nuwe Testament) as vir almal wat dit lees as normatiewe literatuur. Dit ontneem gelowiges nie die moontlikheid om sinvol te teologiseer nie, maar lê juis op hulle die verantwoordelikheid om met groot omsigtigheid te praat oor God en sy werk.

Teologisering moet nie bloot 'n magspel wees waardeur eie oortuigings gelegitimeer, opposisie gemarginaliseer en God se soewereiniteit ingeperk word nie. Wie met verantwoordelikheid wil teologiseer, moet altyd besonder bedag wees op meesternarratiewe wat pretendeer om universele verstaanswaarhede te wees.

In die lig van die voorafgaande kan enige vorm van Ortodoksie wat die illusie skep van harmonie en 'n organiese geheel, nie meer gehandhaaf word nie. Die totalitêre aard van so 'n Ortodoksie gaan in teen die grein van die finale kanon wat as beroepsgrond aangevoer word. Die wesenlike aard van die Ou- en Nuwe-Testamentiese kanon maak ' $n$ teologisering met 'n dialekties-kritiese aanslag die vanselfsprekendste wyse van omgang met die Skrif.

Die voorafgaande studie bring twee indringende vrae na vore:

* Begryp teoloë die volle omvang van die stelling dat die Woord van God in mensewoorde, dit wil sê mensgemaakte tekste na ons kom?

* In hoe verre is die gangbare 'kerklike' teologie van die verskillende kerklike tradisies van ons dag meesternarratiewe wat pretendeer om universele waarheid te wees en daarom opposisie marginaliseer? 


\section{Endnotas}

1 Hiermee bedoel Hutcheon (1988:5) 'those well-known and popular novels which are both intensely selfreflected and yet paradoxically also lay claim to historical events and personages'.

2 Narratiewe in die wydste $\sin$ van 'belletristiese of artistieke prosa of fiktiewe verhale ... [g]eskiedskrywing, koerantberiggewing, gevallestudies en vele ander geskrewe tussenvorme sowel as ... orale uitinge in gesprekke en kommentare, ... waardeur die ideologiese stramien van die denke van individue sowel as van die gemeenskap sigbaar word' (Du Plooy 1993:220).

3 Ek verkies en gebruik verder die term kontranarratiewe.

4 Met moderne literêre kanon word bedoel 'een verzameling van werken en outeurs die door cen sociale groep of literair circuit als waardevol erkend worden, en die als referentiepunt voor die sociale groep of dat literair circuit fungeren' (Moerbeek, in Ohlhoff 1995:40).

5 Met kanoniseriñg word verder in hierdie artikel bedoel die toekenning van gesag aan standpunte, vertellings, selfstandige tekste, groter literêre eenhede en ook instellings. Daarmee word nie bedoel '(textually) unalterable' nie (Deist 1995:69). Ek verwys na dié stadium van die onveranderbaarheid van religieuse tekste as finale kanonisering.

6 Alle teksverwysings volg die versindeling van die Nuwe Afrikaanse Vertaling.

\section{Literatuurlyśs}

Breytenbach, A P B 1979. Die verband tussen en die ontwikkeling in die profetiese uitsprake in die boek Hosea. DD-proefskrif, Universiteit van Pretoria.

- 1983. Die boodskap van die boek Jona. HTS 39, 135-140. 1985. Hosea 12:1-14. HTS 41/2, 197-207.

1987. Die redaksionele geskiedenis van die boek Hosea. HTS 43/4, 732740.

1996. Hosea 2:4-15 teen die agtergrond van Israelitiese regsgebruike. Acta Theologica 16/1, 24-40.

Brink, A P 1988. Die postmodernistiese roman: 'n Skakel met die 18de eeu? TLW 4/4, 378-393.

Cross, F M 1973. Canaanite myth and Hebrew epic. Cambridge: Harvard. Deist, F 1984. A concise dictionary of theological terms. Pretoria: J L van Schaik. 1995. Canonical literature: Some ideology-critical observations, in Nel \& Van den Berg 1995:66-80.

Degenaar, J 1995. The text is an episode in an all-encompassing textuality, in $\mathrm{Nel}$ \& Van den Berg 1995:3-21. 
Du Plooy, H 1993. Die narratologie in die kontemporêre Suid-Afrikaanse literatuur-studie. TLW 9/3 \& 4, 219-234.

Eynikel, E 1996. The reform of king Josia and the composition of the Deuteronomistic history. Leiden: Brill.

Fokkema, D 1993. European canon of literature? European Review 1/1, 21-29.

Gräbe, I 1988. Introduction: Postmodernism and reading literature. TLW 4/4, 359377.

Grové, A P 1982. Letterkundige sakwoordeboek vir Afrikaans. Goodwood: Nasou. Hambidge, J 1992a. Post-modernisme (Deel 1). Tydskrif vir Letterkunde 30/2, 6268.

1992b. Post-modernisme (Deel II). Tydskrif vir Letterkunde 30/3, 48-57.

Hasel, G F 1972. Old Testament theology: Basic issues in the current debate. Grand Rapids: Eerdmans.

Holbert, J C 1996. Deliverance belongs to Yahweh: Satire in the book of Jonah, in Davies, P R (ed) 1996, The prophets. Sheffield: Academic Press.

Hutcheon, L 1988. A poetics of postmodernism. London: Routledge.

Ibsch, E 1993. Fact and fiction in post-modernist writing. $T L W 9 / 2,185-193$.

Jeismann, K-E 1985. Geschichte als Horizont der Gegenwart. Paderborn: Ferdinand Schäningh.

Jeremias, J 1996. Hosea und Amos. Tübingen: J C B Mohr. (Forschungen zum Alten Testament.)

Liebenberg, W 1988. Postmodernism: Progressive or conservative? TLW 4/3, 281286.

Loader, J A 1975. Aspekte van menslike mag in die Ou Testament. DTheol-proefskrif, Rijksuniversiteit Gröningen.

Murphy, R E 1984, A response to 'The task of Old Testament theology'. HBT 6/1, 65-72.

Nederduitsch Hervormde Kerk van Afrika 1987. Diensboek. Pretoria: Kital. 1995. Notule van die Algemene Kerkvergadering 1995. Argief van die Nederduitsch Hervormde Kerk, Pretoria.

Nel, P J \& Van den Berg, D J (eds) 1995. Concepts of textuality and religious texts. Bloemfontein: UOVS. (Acta Academica, Supplementum I.)

Odendal, $\mathrm{F} \mathrm{F}$ et al 1994. Verklarende handwoordeboek van die Afrikaanse taal. Midrand: Perskor.

Ohlhoff, H 1993. Kanon en kanonvorming. Tydskrif vir Letterkunde 31/4, 58-66.

Olivier, B 1988. The critical difference: Deconstruction and postmodernism. TLW 4/3, 287-298. 
Readings, B 1991. Introducing Lyotard. London: Routledge.

Ryan, R 1988. Introduction: Postmodernism and the question of literature. TLW $4 / 3,247-258$.

'Van der Woude, A S 1976. Micha. Nijkerk: G F Callenbach. (POT.)

1982. Haggai Maleachi. Nijkerk: G F Callenbach. (POT.)

1984. Zacharia. Nijkerk: G F Callenbach. (POT.)

Van Heerden, E 1994. Vanuit eie werk: Die skrywer as historiograaf. Tydskrif vir Letterkunde 32/3, 1-15

1997. Postmodernisme en prosa. Kaapstad: Human \& Rousseau.

Van Selms, A 1980. Jeremia, deel 1. Nijkerk: G F Callenbach. (POT.)

Viljoen, H 1988. Spieël, kamer van spieëls: Oor postmodernisme en representasie.

TLW 4/4, 417-426. 